\title{
Perspectives on managing fisheries for community wellbeing in the face of climate change
}

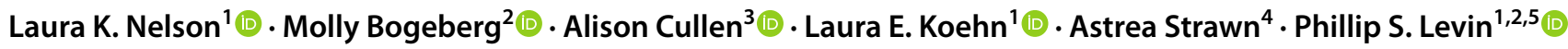

Received: 9 June 2021 / Accepted: 27 November 2021 / Published online: 14 January 2022

(c) The Author(s), under exclusive licence to Springer-Verlag GmbH Germany, part of Springer Nature 2021

\begin{abstract}
Coastal communities are being impacted by climate change, affecting the livelihoods, food security, and wellbeing of residents. Human wellbeing is influenced by the heath of the environment through numerous pathways and is increasingly being included as a desired outcome in environmental management. However, the contributors to wellbeing can be subjective and the values and perspectives of decision-makers can affect the aspects of wellbeing that are included in planning. We used Q methodology to examine how a group of individuals in fisheries management prioritize components of wellbeing that may be important to coastal communities in the California Current social-ecological system (SES). The California Current SES is an integrated system of ecological and human communities with complex linkages and connections where commercial fishing is part of the culture and an important livelihood. We asked individuals that sit on advisory bodies to the Pacific Fisheries Management Council to rank 36 statements about coastal community wellbeing, ultimately revealing three discourses about how we can best support or improve wellbeing in those communities. We examine how the priorities differ between the discourses, identify areas of consensus, and discuss how these perspectives may influence decision-making when it comes to tradeoffs inherent in climate adaptation in fisheries. Lastly, we consider if and how thoughts about priorities have been affected by the COVID-19 pandemic.
\end{abstract}

Keywords Adaptation · California Current · Pacific Fisheries Management Council · Tradeoffs · Q methodology

Laura K. Nelson

lknelson@uw.edu

Molly Bogeberg

molly.bogeberg@tnc.org

Alison Cullen

alison@uw.edu

Laura E. Koehn

laura.koehn216@gmail.com

Astrea Strawn

astrea.strawn@gmail.com

Phillip S. Levin

pslevin@uw.edu

1 School of Environmental and Forest Sciences, University of Washington, Box 352100, Seattle, WA 98195-2100, USA

2 The Nature Conservancy of Washington, 74 Wall St, Seattle, WA 98121, USA

3 Evans School of Public Policy, University of Washington, Box 353055, Seattle, WA 98195-3055, USA

4 The Nature Conservancy of Oregon, 821 SE 14th Ave, Portland, OR 97214, USA

5 School of Marine and Environmental Affairs, University of Washington, Box 355685, Seattle, WA 98195-5685, USA

\section{Introduction}

Coastal communities are at risk from many impacts of climate change (IPCC, 2019). Coastal regions are twice as densely populated as inland areas (Sale et al., 2014), and in the United States nearly $40 \%$ of the population lives in coastal counties even though they constitute less than $10 \%$ of the land in the contiguous U.S. (Feist and Levin, 2016). This area would rank third in global gross domestic product (GDP) if it was its own country, behind only China and the United States as a whole (NOAA, 2014). In addition to threats from sea level rise and increasingly intense and frequent storms, climate change will have profound effects on the structure and function of marine ecosystems (Perry et al., 2005; Doney et al., 2012; Olsen et al., 2020), and thus the communities that depend on the abundance and availability of marine resources (Ainsworth et al., 2011). The livelihoods and food security of many are threatened by these changes (Badjeck et al., 2010; Selig et al., 2018). Moreover, cultural values tied to the ocean and a sense of place are also in jeopardy for coastal communities, particularly those that are engaged in fisheries (Poe et al., 2014). 
The health of ecosystems influences human wellbeing (Diaz et al., 2015). Following Breslow and colleagues (2016), we define wellbeing as "the state of being with others and the environment which arises when human and ecosystem needs are met, when individuals and communities can act meaningfully to pursue their goals, and when individuals and communities enjoy a satisfactory quality of life." This definition originated in work done by Coulthard et al., (2011) and McGregor (2008), and has been adapted to include the environment by others (Armitage et al., 2012). While there is increasing recognition of the importance of including social data, including measures of wellbeing, in socioecological system management and conservation (Kittinger et al., 2014; Hicks et al., 2016; Bennett et al., 2017), assessments of wellbeing and social vulnerability, particularly those that occur alongside biophysical assessments of environmental conditions, often rely predominantly on quantitative economic or demographic data (Colburn et al., 2016; Harvey et al., 2020). While this practice has benefits, including scalability and the use of secondary data, it often leads to the omission of qualitative evaluation of social and cultural aspects of wellbeing such as the ability to harvest and consume traditional foods (Donatuto et al., 2011), a sense of place (Poe et al., 2016), and opportunities for livelihoods and recreation (Breslow et al., 2017). It can also fail to account for community values; for example, in the fisheries sector, job satisfaction and lifestyle may be valued more highly than economic benefits (Pollnac and Poggie, 2008).

The institutions and governance systems that manage natural resources within social-ecological systems (SESs) also affect wellbeing (Ostrom, 2009). Individuals within those governance systems hold differing values (Rockeach, 2008), which has the potential to affect decision-making processes that impact wellbeing. For example, risk assessments are shaped by the values and knowledge of those conducting the assessments since they determine what endpoints are measured and what outcomes are considered desirable (Renn, 2008). Values also affect the evaluation of tradeoffs (Hicks et al., 2009; Levin et al, 2021), a key component of ecosystem-based management (EBM) (Link 2010). These evaluations have social and economic consequences for the wellbeing of individuals in an SES whose values may or may not align with those conducting the work. Therefore, it is essential to explore the values and perspectives of managers within systems to investigate how they may be shaping current management priorities and objectives.

In this paper, we build on the growing body of literature examining the role of values and perspectives in environmental management (Satterfield et al., 2013; Chan et al., 2016; Donatuto et al., 2020; Levin et al., 2021). This is important because communities have value-driven definitions of environmental health (Donatuto et al., 2011), and the omission of cultural dimensions of social-ecological systems such as values, identity, and knowledge (Poe et al., 2014), can lead to management decisions that are based on incomplete understanding of the system (Berkes, 2012). Our general objective was to investigate perspectives held by actors engaged in fisheries management about how a variety of environmental and social issues may affect coastal community wellbeing. Specifically, we used Q methodology to investigate differences in prioritization of a variety of issues faced by fishing communities on the West Coast of the USA and considered how the emergent perspectives may affect decisions in fisheries management. We also explored whether the challenges faced by the industry during the COVID-19 pandemic affected how issues were prioritized.

\section{Methods}

\section{Study system: the California Current SES}

The focal system in this study was the California Current Large Marine Ecosystem (CCLME) - a highly productive eastern boundary current system that encompasses the ocean and coastal environments from southern British Columbia, Canada to Baja California, Mexico. The coupled SES of the California Current supports the social systems, sense of place, and wellbeing of coastal communities (Breslow et al., 2016). Home to at least 125 fishing communities (Norman et al., 2007), the fishing industry supports 160,000 jobs in Washington, Oregon, and California (NMFS, 2017). The total 2016 commercial landing revenue across all three states was $\$ 688.9$ million with an estimated $\$ 2.3$ billion in expenditures related to recreational fishing (NMFS, 2018). The consequences of exposure to climate impacts are already apparent in the CCLME, threatening the benefits communities receive from the system. Consequences of climate change including ocean warming, ocean acidification (OA), and harmful algal blooms have had, and are projected to continue to have, major impacts on salmon (Crozier et al., 2019), Dungeness crab (Moore et al., 2020; Fisher et al., 2021), and other fisheries (Hodgson et al., 2018). Notable events like the "warm blob" heatwave of 2014 (Bond et al., 2015; Wells et al., 2015) and mass larval mortality events at shellfish hatcheries due to OA (Barton et al., 2015) have shown the harmful effects of these changes. The management of federal fisheries in the CCLME is the responsibility of the Pacific Fisheries Management Council (PFMC), one of eight regional councils in the USA. This work is particularly relevant for the PFMC at this time as the Council has initiated work to assess effects of climate change on fishing communities as part of their Climate and 
Fig. 1 Description of project workflow and information about participants in each component of the study

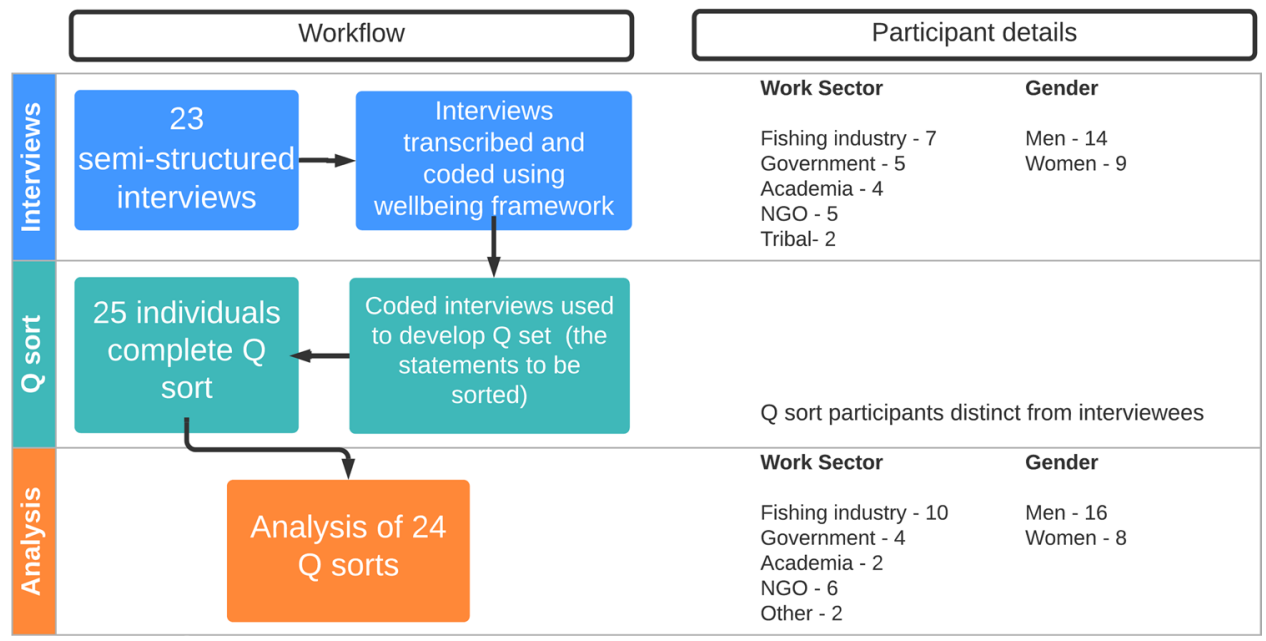

Communities Initiative ${ }^{1}$ and is considering how to incorporate community impacts into its decision-making.

\section{Q methodology}

Q methodology is a structured approach for studying human subjectivity which uses both quantitative and qualitative techniques to identify common perspectives using a rank ordering exercise and factor analysis (Stephenson, 1953; Brown, 1980). The intent is to explore discourses and uncover consensus and divergent views that exist within a group (Brown, 1999). A discourse describes an individual's worldview, their "way of seeing and talking about something" (Barry and Proops, 1999). The Q method has recently seen increasing use in conservation and natural resource management (Gruber, 2011; Ray, 2011; Cairns, 2012; Armatas et al., 2016), including in fisheries and other marine resource management sectors (Carr and Heyman, 2012; MacDonald et al., 2015; Pike et al., 2015; Loring and Hinzman, 2018).

We employed Q methodology to explore perspectives of individuals involved in fisheries management concerning fishing community wellbeing. The structure of a typical Q study involves the creation of the $\mathrm{Q}$ set (the items to be sorted), sorting or ranking those items, followed by factor analysis and interpretation. During the sort, participants place the $\mathrm{Q}$ set into a pre-determined, semi-normal distribution along a spectrum such as most important to least important or most agree to least agree (Brown, 1980; Webler et al 2009; Watts and Stenner, 2012). Factor analysis is used on the completed $\mathrm{Q}$ sorts to reduce the dimensionality of the data and generate idealized Q sorts which can be interpreted as common perspectives held by members of the group. See Fig. 1 for a summary of the overall workflow of this study and information on the participants.

\footnotetext{
${ }^{1}$ https://www.pcouncil.org/actions/climate-and-communities-initi ative/.
}

\section{Q set}

The first step in Q methodology is to develop the collection of statements or items that will be sorted by participants. The $\mathrm{Q}$ set can be sourced from interviews, literature review, or focus groups, and should cover a broad range of perspectives (Stephenson, 1953). We developed the $\mathrm{Q}$ set for this study using 23 semi-structured interviews that were conducted with individuals affiliated with or closely connected to PFMC, all of whom possess a depth of knowledge regarding fisheries on the West Coast. The interviewees came from a variety of backgrounds and work in the fishing industry, state or tribal agencies, NGOs, and academia. We asked interviewees a series of questions about recent trends and developments in West Coast fisheries, what they saw to be strong trends and drivers of change, and how West Coast fishing communities and fish stocks may be affected by climate change (see Appendix 1 for a sample interview script). Interviews were transcribed and deductively coded in ATLAS.ti using the typology of human wellbeing framework developed by Breslow and colleagues (2016).

The wellbeing framework is structured around four constituents of wellbeing: (1) connections - being with others and the environment; (2) conditions - when human needs are met; (3) capabilities - individuals and communities are enabled to pursue their goals; and (4) cross-cutting - a satisfactory quality of life is sustained. The constituents are broken down into increasingly more specific components which focus on aspects of wellbeing that managers and decision-makers may have influence over (Sojka, 2014; see Breslow et al., 2016 and 2017 for additional framework details). Utilizing this framework, we derived 158 statements about community or individual wellbeing from the interviews. We used a structured approach to generate the Q set (Watts 
and Stenner, 2012), using the wellbeing framework to identify the range of themes we sought to cover with the final set of statements. The statements were categorized by the attribute of wellbeing with which they most closely aligned and evaluated for clarity and fidelity to the aspect of wellbeing they were slated to represent. Initially, 42 statements were selected for the Q set that represented a variety of environmental, social, and regulatory conditions. Efforts were made to retain the language used by the interviewee, though some statements were reworded for clarity or generalized if the direct quote referred to a specific fishery. After pilot testing, several statements were cut because testers felt they were unclear or redundant, and the final Q set consisted of 36 statements that represented most attributes in the connections, conditions, and capabilities constituents of wellbeing (Table 1).

\section{P set}

Following the guidance of Webler and colleagues (2009), we ensured that the participants of the Q study (the P set) represented a variety of opinions and perspectives. We recruited participants from the advisory bodies to PFMC, groups that advise the Council on fishery management plans and annual measures. Twenty-five individuals from each state part of PFMC (Washington, Oregon, California, and Idaho) participated in the study. They represent the fishing industry,

Table 1 Q set statements and associated constituent of wellbeing

\begin{tabular}{|c|c|c|}
\hline & Statement & Constituent of wellbeing \\
\hline 1 & There is a demand from consumers for local and sustainable seafood & Conditions \\
\hline 2 & Coastal communities have plans in place in to deal with coastal hazards like tsunamis & Conditions \\
\hline 3 & Fishers have or can access the resources to weather temporary financial stresses due to a downturn in a fishery & Conditions \\
\hline 4 & Extreme and unpredictable ocean conditions threaten fisher safety & Conditions \\
\hline 5 & Direct-to-consumer selling opportunities exist for local fisheries & Conditions \\
\hline 6 & Seasonal aquaculture jobs are available for fishers to supplement fishing income & Conditions \\
\hline 7 & Small, independently owned fisheries can coexist with larger, vertically integrated companies & Conditions \\
\hline 8 & Fishers can afford to live in the coastal communities they have traditionally resided in & Connections \\
\hline 9 & The fishing industry reduces its fuel consumption and emissions & Conditions \\
\hline 10 & Fishing communities have access to quality healthcare & Conditions \\
\hline 11 & Water quality issues caused by climate change prevent species from being harvested & Conditions \\
\hline 12 & Working waterfronts are going away & Connections \\
\hline 13 & Expanding offshore development has conflicts with fishing & Connections \\
\hline 14 & Commercial and recreational fishers work together rather than argue over how to divide quotas & Connections \\
\hline 15 & Society views the harvest of sustainable seafood as an integral component of a healthy ocean & Connections \\
\hline 16 & Children of fishers want to go into the fishing industry & Connections \\
\hline 17 & Conservation groups work more collaboratively with the fishing industry & Connections \\
\hline 18 & There are more people of color and women in fisheries management & Connections \\
\hline 19 & Subsistence and cultural fishing practices are threatened due to shifting availability of resources & Capabilities \\
\hline 20 & Tourism options are developed to support the local economies in fishing communities & Capabilities \\
\hline 21 & Retraining and other job opportunities are available if people decide to move out of fishing & Capabilities \\
\hline 22 & There is more stakeholder engagement in fisheries management & Capabilities \\
\hline 23 & When responding to uncertainty, novel management approaches are created rather than building on old models & Capabilities \\
\hline 24 & Development of new sources of renewable energy eases the need for dams and hydropower & Capabilities \\
\hline 25 & Fishery management policies are based on social equity as well as economic efficiency & Capabilities \\
\hline 26 & The multi-generational, successful seasonal fishery-based lifestyle is viable & Connections \\
\hline 27 & Fishers are not stuck in individual fisheries but have the flexibility to migrate between them when conditions warrant & Capabilities \\
\hline 28 & The understanding of how socioeconomic and ecosystem indicators fit together is improved & Capabilities \\
\hline 29 & Fishers and managers can prepare and respond to changes in the availability of fish & Conditions \\
\hline 30 & Fishing infrastructure improvements needed to deal with sea level rise are supported by the community & Conditions \\
\hline 31 & Cost effective technology improves accountability without fishers having to absorb the costs & Capabilities \\
\hline 32 & Technology is developed to help fishers determine where not to fish to avoid protected species & Capabilities \\
\hline 33 & The pool of qualified crew is reduced due a decrease in training opportunities & Capabilities \\
\hline 34 & Ocean literacy is woven into curriculum for students starting in elementary school & Connections \\
\hline 35 & Impacts of climate change threaten the availability of target species & Connections \\
\hline 36 & Active recruitment of young fishers lessens the impacts of the aging of the fleet & Connections \\
\hline
\end{tabular}


Fig. 2 Q board distribution

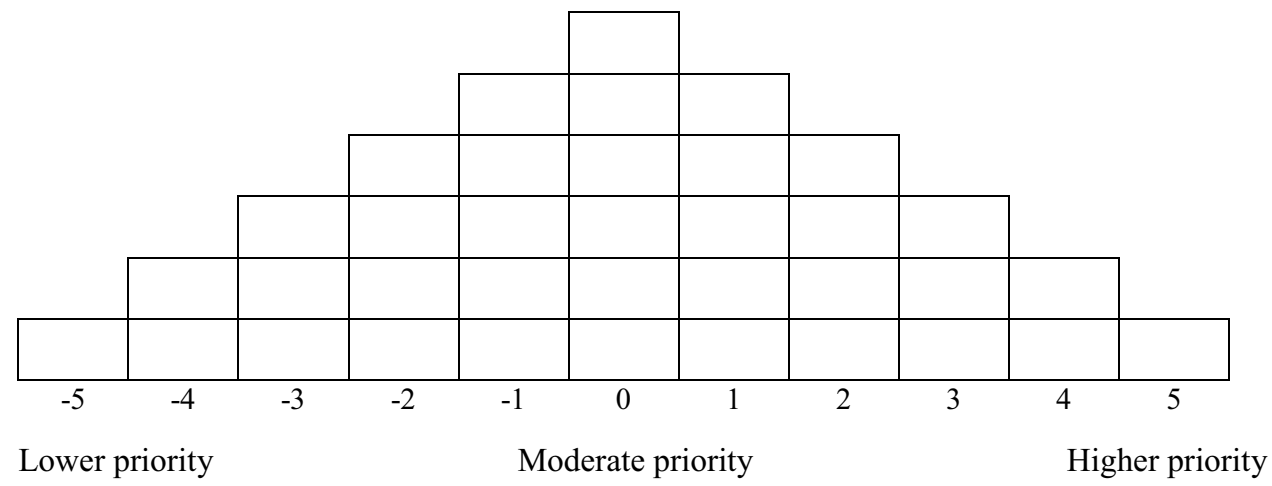

academia, state and tribal governments, conservation, and sport or charter interests, reflective of the overall makeup of the advisory subpanels. Because the aim of the Q method is to understand the internal frame of reference of individuals (Cairns 2012), meaningful results can be achieved with small samples (12-40 participants, e.g., Cairns 2012; Sandbrook et al., 2013). Thus, our sample size of 25 was within typical range, and adequately captured a diversity of experiences (Watts and Stenner, 2012).

\section{Q sort}

Because of the ongoing COVID-19 pandemic at the time of our study, we used an online platform call Q Method Software to conduct Q sorts. ${ }^{2}$ Each participant was guided through the $\mathrm{Q}$ sort using the Zoom video conferencing platform. After obtaining consent from the participants, the sessions were recorded to capture the explanations of participants during their sorts. Prior to completing the sort, each participant answered some background demographic and environmental worldview questions (Appendix 2) (McNeeley and Lazrus, 2014; Cullen et al., 2018). Next, participants were given the prompt, "Consider the condition described by the statement-is addressing it a higher, moderate, or lower priority when it comes to supporting or improving fishing community wellbeing?" Individuals then conducted a preliminary sort where each statement was ranked as either a higher, moderate, or lower priority. This was followed by the detailed sort where participants placed the statements on the $\mathrm{Q}$ board where column 5 represented their highest priority and -5 was the lowest (Fig. 2). Participants were instructed to consider this a relative ranking; accordingly, some statements with lower rankings may still be things they think are important for coastal communities. Participants were asked to explain the rationale for their sorting choices as they completed the sort. Following the completion of the

\footnotetext{
2 https://qmethodsoftware.com/.
}

Q sort, participants were asked the following two questions regarding the degree to which the COVID-19 pandemic may have anchored their responses or contributed to their thoughts about community needs:

1. Knowing what you know now about how the industry has been affected by the COVID-19 crisis, are there statements from the $\mathrm{Q}$ sort that you would re-prioritize? Are there statements that you ranked higher today than you might have a few months ago?

2. Are there any issues that were not part of the sorting activity that you would add based upon lessons learned from COVID-19?

During this time, participants were also encouraged to continue any explanation for their sorting choices and express any final thoughts.

\section{Statistical analyses}

Once all participants completed the exercise, 24 of the $25 \mathrm{Q}$ sorts were analyzed using qmethodsofware.com (Lutfallah and Buchanan, 2019) and the qmethod R package (Zabala, 2014). One individual felt that they had not been able to complete the activity in a way that accurately represented their views and asked that their $\mathrm{Q}$ sort be withdrawn from the study. We used principal component analysis to reduce the data into factors which were rotated using varimax rotation to maximize the variance explained and to attempt to associate individuals with just one factor. In $\mathrm{Q}$ method, there is not one objectively correct solution regarding the number of factors to extract (Watts and Stenner, 2005), it is instead a process guided by the amount of variability explained, eigenvalue test, screeplot inspection, and the interpretability and theoretical significance of the factors (Brown, 1980; Watts and Stenner, 2012). Based upon evaluation of these criteria, three factors were best supported (see Appendix 3 for details.) 
The resulting factors are idealized $\mathrm{Q}$ sorts representing the discourses of the group. As part of the analysis, each statement receives an integer score representing its placement in the idealized Q sort. Each statement also has a $z$-score, the weighted average of the statement scores from the Q sorts that load on that factor (Zabala et al., 2018). The analysis identifies distinguishing and consensus statements, those where the $z$-scores are statistically different $(p<0.05)$ or similar to other perspectives, respectively. The discourses (i.e., ways of thinking or worldviews) are interpreted by comparing the ranking of statements as well as considering which had distinguishing or consensus status.

\section{Results}

Twenty-one of the sorts loaded significantly onto the three factors; two sorts were confounded (associated with two factors), while one sort did not align with any of the emergent perspectives. The three factors represent the common perspectives or discourses held by the participants which we refer to as follows: (1) Collaboration is Key, (2) Fishers Forward, and (3) Climate and Society. The discourses are described below and the distribution of statements in each of the idealized sorts is shown in Fig. 3. A complete

\section{Collaboration is Key}

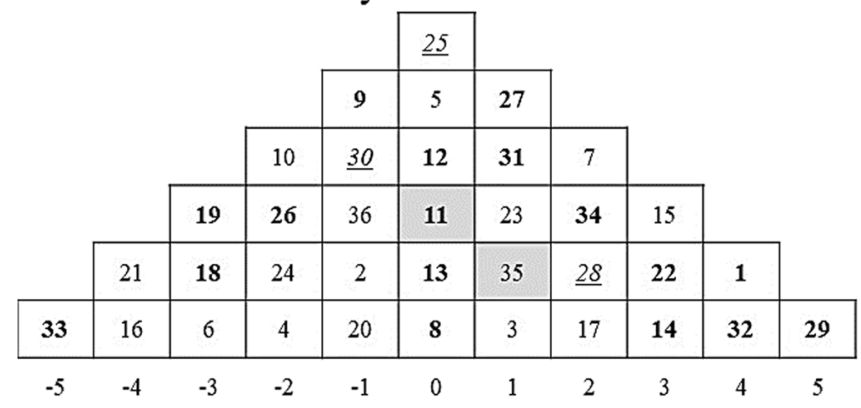

\section{Climate and Society}

\begin{tabular}{|c|c|c|c|c|c|c|c|c|c|c|}
\hline & & & & & 36 & \multirow[b]{2}{*}{10} & & & & \\
\hline & & & & 34 & 2 & & & & & \\
\hline & & & 31 & 30 & 3 & 23 & 1 & & & \\
\hline & & 22 & 17 & 27 & 5 & 32 & $\underline{28}$ & 24 & & \\
\hline & 14 & 26 & 20 & 33 & 7 & $\underline{25}$ & 12 & 18 & 11 & \\
\hline 6 & 16 & 8 & 9 & 4 & 21 & 15 & 29 & 13 & 19 & 35 \\
\hline-5 & -4 & -3 & -2 & -1 & 0 & 1 & 2 & 3 & 4 & 5 \\
\hline
\end{tabular}

Fig. 3 Distribution of statements in each discourse. Numbers in bold are distinguishing statements, those italicized and underlined are consensus statements. Gray boxes note the statements that explicitly list of statements with associated factor scores and distinguishing or consensus status can be found in Appendix 3.

\section{Discourse analysis}

\section{Factor A-Collaboration is Key}

The first discourse, Collaboration is Key, is defined by belief that collaboration in the fisheries world is crucial for the wellbeing of communities. The eight participants in this group were the oldest on average and this was the most male-dominant of the three discourses (Table 2). Statements explicitly calling out collaboration were ranked highly, as were those that implied a partnership. This group values positive working relationships between groups typically engaged in fisheries management including conservation organizations, recreational and commercial fishers, and prioritizes stakeholder engagement. Conservation provoked polarizing reactions; participants described constructive and contentious relationships with conservation groups which seemed to vary by fishery and region. In addition to valuing collaboration between the industry and outside groups, they also sought a balance within the industry itself of larger and smaller enterprises.
Fishers Forward

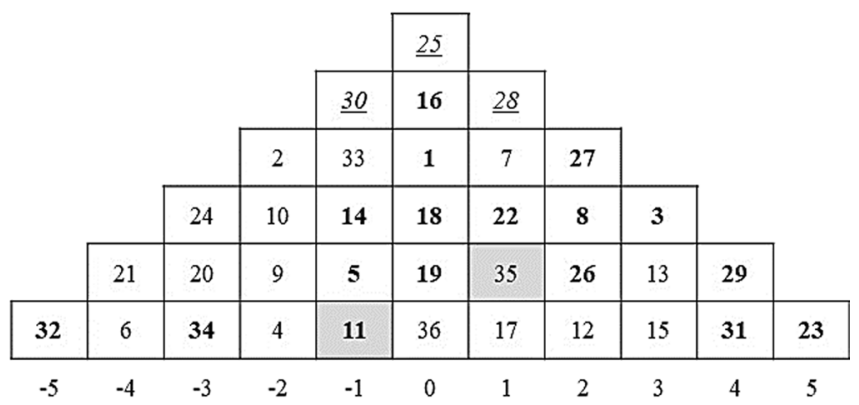

mentioned climate change. Column 5 is the highest priority while -5 represents the lowest 
Table 2 Factor A characteristics

\begin{tabular}{|c|c|c|c|c|c|c|}
\hline Name & Loading Q sorts & $\%$ variance explained & eigenvalues & Average age $(s d)$ & Genders & Work sectors \\
\hline Collaboration is Key & 8 & 15 & 3.6 & $68(11.3)$ & $7 \mathrm{M}, 1 \mathrm{~F}$ & $\begin{array}{l}\text { Industry, govern- } \\
\text { ment, academia, } \\
\text { other }\end{array}$ \\
\hline \multicolumn{6}{|l|}{ Top 3 priorities } & $z$-scores \\
\hline \multicolumn{6}{|c|}{ Fishers and managers can prepare and respond to changes in the availability of fish } & 2.097 \\
\hline \multicolumn{6}{|c|}{ There is a demand from consumers for local and sustainable seafood } & 1.982 \\
\hline \multicolumn{6}{|c|}{ Technology is developed to help fishers determine where not to fish to avoid protected species } & 1.808 \\
\hline
\end{tabular}

This group's prioritization of engagement extends to society-at-large as they hope people consider sustainable seafood an integral part of a healthy ocean. Getting consumers to demand local and sustainable seafood is also very important to this discourse, beliefs underscored by the value placed upon starting the cultivation of ocean literate citizens at a young age. One group member stressed the importance of consumers:

My primary interest is that there's a well-developed market for the product and then all these other things fall in place because it provides economic benefits to the community, it helps build infrastructure, it makes people want to be in the fishery, all of those things.

Despite the prioritization of a variety of sectors working together, the focus was on groups already commonly engaged in fisheries management. Increasing diversity and threats to subsistence and cultural fishing were lower priorities for this group than the other discourses. Though they were still of moderate concern, in the Collaboration is Key discourse addressing aspects of the built environment, including offshore development and the status of working waterfronts, were also a lower priority compared to either of the other groups. Less important issues involved the fisheries labor force itself, specifically retraining or aquaculture options and the pipelines that recruit or train people to fish. This is perhaps reflective of the perception that other issues need to change to make the fishing industry a more attractive work sector. For instance, one participant noted,
When there's no place for people to go work...I don't think those [training programs] are particularly ethical or doing a very good job. I've heard examples of ones that do a good job, but I struggle with training people who potentially won't have a job.

\section{Factor B-Fishers Forward}

The second discourse, Fishers Forward, was populated by three women and three men, and explained $14 \%$ of the overall variance (Table 3 ). This discourse is characterized by the prioritization of conditions that support the adaptive capacity of individual fishers and the resilience of the fishing industry. Those holding this perspective connect community wellbeing to the sustainability of a traditional fishing lifestyle and are focused on a mix of actionable items which would directly benefit fishers. These include improving financial support and the development of technology to assist with requirements for independent observers on fishing vessels. Participants in this discourse embrace traditional regulatory tools, but they want these tools to evolve to meet the current challenges. These individuals also highlighted the need for flexibility where it has previously been limited by regulations. This discourse prioritizes areas where managers can have agency, ranking addressing environmental changes and their impacts on fish as only moderate priorities, while considering their ability to prepare for those changes as one of the

Table 3 Factor B characteristics

\begin{tabular}{|c|c|c|c|c|c|c|}
\hline Name & $\begin{array}{l}\text { Loading } \\
\text { Q sorts }\end{array}$ & $\begin{array}{l}\% \text { variance } \\
\text { explained }\end{array}$ & eigenvalues & Average age $(s d)$ & Genders & Work sectors \\
\hline Fishers Forward & 6 & 14 & 3.4 & $55(15.0)$ & $3 \mathrm{M}, 3 \mathrm{~F}$ & $\begin{array}{l}\text { Industry, gov- } \\
\text { ernment, } \\
\text { NGO }\end{array}$ \\
\hline \multicolumn{6}{|l|}{ Top 3 priorities } & $z$-score \\
\hline \multicolumn{6}{|c|}{$\begin{array}{l}\text { When responding to uncertainty, novel management approaches are created rather than } \\
\text { building on old models }\end{array}$} & 1.925 \\
\hline \multicolumn{6}{|c|}{ Fishers and managers can prepare and respond to changes in the availability of fish } & 1.496 \\
\hline \multicolumn{6}{|c|}{$\begin{array}{l}\text { Cost effective technology improves accountability without fishers having to absorb the } \\
\text { costs }\end{array}$} & 1.153 \\
\hline
\end{tabular}


top issues. One participant summed up that line of thinking by noting:

\section{It's virtually impossible to determine what the future is going to bring from the standpoint of climate. So, if we're responding to it and have the ability to change rapidly and the flexibility to change on an annual basis that really should be sufficient to keep us caught up with the environment and we can spend our time, from an administrative, management, and policy standpoint, working on things such as figur- ing out how we can get more fish to the fleet and to communities.}

The Fishers Forward discourse places a much higher priority on the preservation of a multi-generational fishing lifestyle relative to Collaboration is Key or Climate and Society. They prioritized the affordability of coastal communities, and the entry of children of fishers into the industry much more highly than the other perspectives. Consistent with the focus on putting resources towards a viable and resilient industry is a deemphasis on economic diversity, including retraining people moving out of fishing, a position shared with Collaboration is Key.

The Fishers Forward discourse includes a strong desire that society has a positive image of sustainable fishing. Even so, this discourse places other society/industry interactions and engagement opportunities, like consumer demand, direct-to-consumer markets, and ocean education, as lower priorities than both other discourses. While Fishers Forward values the development of technology that may benefit fishers' incomes, technology connected to legally protected species was their lowest priority.

\section{Factor C-Climate and Society}

Climate change and its impacts on communities are the highest priorities for the Climate and Society discourse. Seven participants loaded onto this discourse, though one loaded negatively indicating the inverse perspective is held by that individual (Table 4). In contrast to Fishers Forward and their prioritization of adaptive capacity actions, Climate and Society emphasizes the need to take a systemlevel approach by addressing the drivers of vulnerability and promoting resilience. The biggest concerns for those holding this perspective are how climate change will affect the availability and harvestability of fish, and the communities that will suffer food security and cultural impacts due to those changes. They ranked the development of new renewables to ease the need for hydropower much higher than either of the other discourses, perhaps reflective of their acknowledgement of the importance of renewable energy, and the negative impacts that hydropower can have on fish populations.

They think that tackling these challenging problems is going to require the inclusion of a more diverse set of managers and that ensuring wellbeing means taking a community-oriented approach rather than focusing on sources of resilience just for fishers and the industry. This includes ensuring fishing communities have access to quality health care, that they are prepared for coastal hazards, and that there are accessible economic opportunities outside of fishing. Though the Climate and Society discourse contrasts strongly with Fishers Forward on the prioritization of statements describing components of the traditional fishing lifestyle, they were in exact agreement on the importance of working waterfronts and addressing conflict between fishers and other users in an increasingly busy offshore environment. They value supporting fishing and its infrastructure needs, while acknowledging that the adherence to traditional models may not encourage the flexibility needed to weather a changing climate. Reflecting on the concept of tradition in fishing, one individual said,

We need the ability to not just keep doing what we've been doing, whether that's fishing the same things that have been done for previous years or over multiple generations. This can lead to a lot of stubbornness and not being flexible to take advantage of new opportunities as well as shifting climates...this leads to some challenges on the management front cause there is this idea that because something has been done one way

Table 4 Factor $C$ characteristics

\begin{tabular}{|c|c|c|c|c|c|c|}
\hline Name & Loading Q sorts & $\begin{array}{l}\% \text { variance } \\
\text { explained }\end{array}$ & Eigenvalues & Average age $(s d)$ & Genders & Work sectors \\
\hline Climate and Society & 7 (1 negative loading) & 13 & 3.2 & $59(11.5)$ & $5 \mathrm{M}, 2 \mathrm{~F}$ & $\begin{array}{l}\text { Industry, } \\
\text { NGO, gov- } \\
\text { ernment }\end{array}$ \\
\hline \multicolumn{6}{|l|}{ Top 3 priorities } & $z$-score \\
\hline \multicolumn{6}{|c|}{ Impacts of climate change threaten the availability of target species } & 2.075 \\
\hline \multicolumn{6}{|c|}{ Subsistence and cultural fishing practices are threatened due to shifting availability of resources } & 1.41 \\
\hline \multicolumn{6}{|c|}{ Water quality issues caused by climate change prevent species from being harvested } & 1.372 \\
\hline
\end{tabular}


Fig. 4 Z-scores for each statement in each perspective. A higher $\mathrm{z}$-score indicates a higher priority statement. Statements with tightly clustered $\mathrm{z}$-scores indicate agreement between perspectives about the relative priority of that issue, while greater distance between points indicates greater disagreement. Distinguishing or consensus status is determined by comparing the absolute difference in statement z-scores with significance thresholds
Statements ordered from most distinguishing at the top to greatest consensus at the bottom. Filled symbols indicate distinguishing statements.

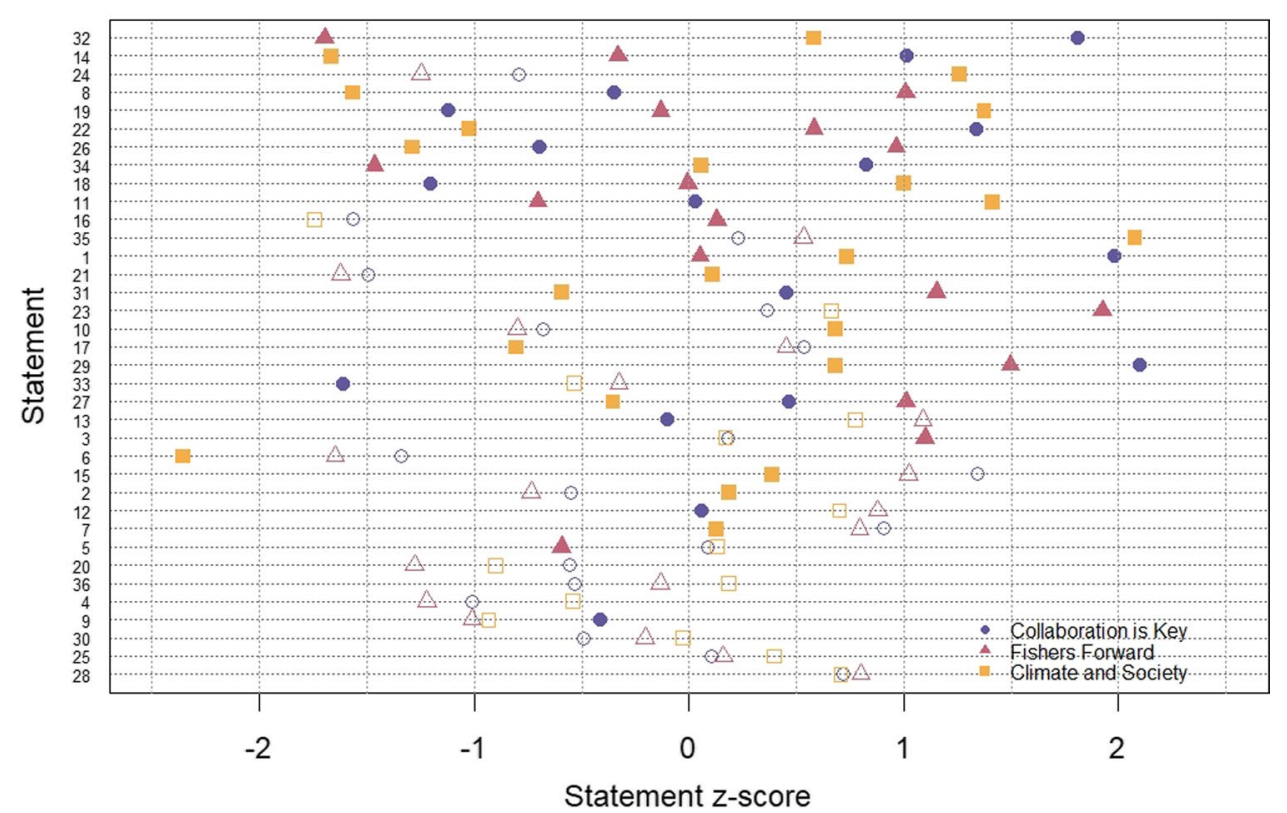

for generations that it shouldn't have to change even though the ocean and communities are changing.

Though Climate and Society is concerned with offshore conflict, they are less concerned with conflict in the management space. In stark contrast to Collaboration is Key, they give low priority to collaboration with conservation, stakeholder engagement, and harmony between recreational and commercial fishers. This likely partially reflects a belief expressed by many, that at least with regards to conservation and stakeholders, a lot of progress has been made in these areas and that while they are very important, they do not need to receive special attention anymore.

\section{Consensus views}

In addition to revealing differences among discourses, we used Q analysis to identify areas of agreement. Of the 36 statements, three were identified as statistical points of consensus across all discourses because there were no significant differences between the $z$-scores for those statements $(p<0.5)$ (Table 7, Appendix 3). Evaluating the content of the consensus statements, as well as the gradient of statements from the most agreement to most disagreement, adds additional understanding to the differences and similarities in priorities held among the discourses (Fig. 4). The consensus statements, 25,28 , and 30 , were in the moderate priority range. Two of the three (25 and 28 ) concerned social issues relevant for fisheries management, specifically a better understanding of the interaction between socioeconomic and ecosystem conditions and the inclusion of some measure of social equity in fisheries management. The other point of consensus was around the need for community support as fishing infrastructure is updated in response to sea level rise. Overall, there was little enthusiasm for the idea of aquaculture jobs as seasonal, supplemental income for fishers and it was the lowest overall priority (overall $z$-score -5.35 ). Participants were most supportive of the concept that fishers and mangers can prepare and respond to changes in the availability of fish (overall $z$-score 4.27).

\section{COVID-19}

We created the Q set used in this study before the onset of the COVID-19 pandemic, but certain conditions described in the Q set are related to issues that were exacerbated by the pandemic. We included questions about COVID19 in our post-sort interview to investigate if anchoring on recent events had affected responses. Fifty percent of the participants reported that COVID-19 had affected the way they prioritized statements. The discourse that people were associated with does not appear to be a factor in who responded that way; individuals from each discourse and those not associated with any replied yes to the question. Those that felt like COVID-19 had affected their rankings stressed the importance of local markets, direct-to-seller opportunities, and demand for local and sustainable seafood. They also noted how the pandemic had highlighted a vulnerability of the industry in its reliance on global supply chains and restaurants. The coping strategies that kept small businesses afloat were acknowledged by some as an opportunity to rethink how fish are sold and marketed 
in the USA, and that we may want to act to solidify the direct-to-consumer channels that were developed out of necessity after broad restaurant closures. One response described that thought process,

Direct-to-consumer selling has made a difference in people making it right now and has people thinking about supply chains and what is the "right way" for fishermen to sell their fish. Fishers can take initiative and be more flexible in who they sell to, the current structure may not be best long term for fishers.

Participants also reflected upon how the need for immediate action affected their responses and how the importance of ongoing needs like economic resilience and community health was underscored by the impacts of the pandemic. One individual commented,

The statements I prioritized were those that I thought could have the most direct or immediate impacts, rather than affecting systematic change. Climate change is not necessarily having immediate effects that are easy to attribute, and I likely would have considered those a higher priority prior to the pandemic. The effects of the food system and seeing the importance of local networks has also been underscored by the effects of COVID-19.

Other common responses included how COVID has highlighted the need for agile management and the ability to respond to uncertainty. One response noted the importance of electronic monitoring in a world where it is challenging to safely have an observer onboard fishing vessels. Supply chains, marketing, and financial literacy were noted as issues people became more concerned about during COVID19 that were not reflected in the Q set. Issues of access and equity were also mentioned, as the barriers to getting out on the water during the pandemic were not distributed equally across fisheries and sectors as was noted by this participant,

Recreational community was specifically impacted, and it impacted people differently depending how reliant you were on public infrastructure, i.e., those that have their boats at a slip vs those who needed to use public boat ramps.

\section{Discussion}

Human wellbeing is connected to the health of the environment (e.g., Frumkin et al. 2017; Bratman et al. 2019), and the wellbeing of those residing in coastal communities is facing pressure from changes to both ecological and social systems (Perry et al., 2010; Willis et at., 2018; Cohen et al., 2019). In Washington, Oregon, and California, communities that are reliant on fishing are particularly vulnerable to environmental change in the California Current (e.g., Fisher et al. 2021). Fishing remains an important livelihood in these communities, providing a source of income and highly valued for contributions to wellbeing like job satisfaction and identity (Holland et al., 2019). How actors in SESs respond to changes is influenced by their perceptions of the best ways to support wellbeing and reduce vulnerability (Eiser et al. 2012). The nature of these challenges, and the complex linkages and feedbacks between people and nature, makes it a difficult task to decide what issues to prioritize in order to best enhance adaptation or build resilience. We used Q methodology to investigate how a group of actors engaged in fisheries management approach that challenge and to explore their perspectives on how to prioritize actions to support or improve the wellbeing of coastal residents, ultimately revealing three emergent discourses focused on the need for collaboration, the future of fishers, and the impacts of climate change on fisheries and communities.

Differences in the nature of issues confronting fishing communities and the scales at which they occur makes prioritization of these issues a challenge (Okamoto et al., 2020), even when it is only a theoretical exercise. Some concepts that we asked participants to consider, like identity and wellbeing, can be particularly hard to evaluate (Satterfield et al., 2013). Many participants expressed having difficulty with the forced distribution in the sort and only being allowed to choose a few top priorities when they thought most of the conditions described in the statements were important. Ultimately, 13 of the 36 different statements received the top ranking during the sorts and 14 received the bottom ranking, reflecting the diversity of opinions still contained within the shared perspectives. The limit on choosing just a few top priorities required that the participants evaluate potential tradeoffs in a manner like those inherent in fisheries management (c.f., Levin et al., 2009). Perceptions and values can shape how people view tradeoffs; what seems to be a tradeoff to some can appear to be mutually beneficial to others (Campbell et al., 2010). In this study, there were a few areas where participants seemed to be making tradeoffs about the scale, either spatial or temporal, at which action should be prioritized.

The three discourses we described differed in the scale of the issues that they prioritized, from individual to community to entire SES level. Nelson et al. (2007) describe similar scalar differences in adaptation versus resilience research, defining adaptation as an actor-orientated approach that focuses on process, governance, and the individual, and resilience studies as a systems-oriented approach that focuses on ecosystem-level connections. The Fishers Forward discourse aligns with the actor-level approach, focusing on individual adaptive actions, while Climate and Society displays the systems-level thinking of resilience, focusing on large ecosystem and societal processes. Collaboration is Key is in the middle of this range, incorporating the governance and process aspects associated 
with adaptation and centering action at the community level. Adaptive capacity of individuals contributes to the resilience of the system (Folke et al., 2010), and resilient systems better retain key functions, benefiting the actors. However, greater system-level resilience does not necessarily result in even distribution of improved wellbeing to individuals in that system (Coulthard, 2012). The concern about the consequences for wellbeing in pursuit of resilience is perhaps best represented here by the way the different perspectives perceive aspects of the traditional fishing lifestyle. Climate and Society are open to change in tradition if the flexibility gained allows for the continued functioning of the system overall, while Fishers Forward associate better wellbeing outcomes with the preservation of current practices, which may limit adaptability. While the quest for wellbeing can support adaptation, in some cases, it can also restrict it (Coulthard, 2012) and strong, place-based identities can hinder a willingness to adapt (Marshall et al., 2012). System resilience may be a positive objective, but the consequences for individual wellbeing should not be ignored, particularly for often overlooked intangibles like cultural values (Satterfield et al., 2013), though improved environmental quality that comes with some social and economic costs can be acceptable to people (Levin et al., 2015).

The second area where we saw divergence in prioritization was along temporal scales; some preferring to focus on reducing current risk and addressing short-term shocks, while others concentrated on measures that may provide long-term resiliency but not necessarily any near-term relief. This is sometimes described as coping versus adapting (Lebel et al., 2006. See also, Thiault et al. 2020). Research on risk perception has shown that individual perceptions are influenced by events that are situated closely in time or space, and also by the level of agency or control that an individual feels to address the risk (Renn, 2008; Cullen and Anderson, 2017). Cognitive bias to focus on the present as opposed to the future can undermine motivation to respond to long-term, gradual threats like climate change (Clayton et al., 2015). Earlier work finds impacts of both short-term climate anomalies, and long-term climate trends, on individual perceptions of livelihood risk and household vulnerability (Cullen and Anderson, 2017).

COVID-19 has resulted in a number of coping behaviors by the fishing industry, governments, and coastal communities including adjusting practices to protect worker health and shifting emphasis from restaurants to online markets; actions that could potentially become adaptations if continued after COVID-19 decreases in severity (Bennett et al., 2020; Love et al., 2020; Stoll et al., 2021). During other shocks experienced by the fishing industry, including the $2015 \mathrm{HAB}$ event on the West Coast, individuals have exhibited both coping and adaptive actions (Moore et al., 2020). The tradeoff between these approaches is that while coping may provide immediate benefits and a reduction in current risks to an acceptable level, it may result in a loss of the flexibility needed to respond to future change
(Nelson et al., 2007). Individuals in the study were dealing with a heightened sense of maintaining this balance as they dealt with the acute market shocks from COVID-19 while also dealing with chronic pressures like climate change. As noted above, 50\% said that COVID-19 had changed the way they ranked statements. Even outside of COVID-19, some participants still had a more near-term strategy for coping with change, preferring to work on issues with less perceived uncertainty than climate change.

The Collaboration is Key discourse was once again in the middle, valuing processes that can begin immediately but where it may take time before benefits are conferred. With their focus on climate, Climate and Society maintained a systemic view, prioritizing things that would make long-term, lasting change. A participant described their thought process about this issue in the following way:

I'm just thinking about, you know, what are the longterm changes we need to see in the management system as a whole. And if we were talking maybe five years, some of these technology ones might raise to the top, like avoiding bycatch because that's more of like okay, how do fishermen get by next year and get more money. They do that by avoiding bycatch and it's good for the environment. We all win. That's great, but that actually is just kind of on the same management treadmill that we're on, just doing it a little bit better.

Shocks like a global pandemic notwithstanding, consideration of tradeoffs in adaptive capacity suggests that shortterm adaptations like investment in financial or technical assets do not provide the same capacity as long-term social change and risk management (Cinner et al., 2018).

A likely source of influence for participants as they considered these tradeoffs is their sense of agency. A sense of agency may influence if and how individuals respond to stressors, including the environmental changes associated with climate change (Brown and Westaway, 2011). Agency also influences risk perception and risk-taking behaviors (Damen, 2019). Agency, or the ability to take action, mobilize resources, and make progress towards objectives aligned with one's values (Sen, 1985), has been identified as a valuable social science indicator (Hicks et al., 2016) and is applied as such in the selfdetermination attribute in the framework used in this study (Breslow et al., 2016). The amount of agency a person feels is related to their ability to improve the wellbeing of themselves and others and make choices that either enables them to act upon their values or compromise because they feel they do not have the power to pursue their ideals (Ibrahim and Alkire, 2007). This can affect objectives in conservation; monetary or cultural costs, and political feasibility may limit what people think can be set as targets (Levin et al., 2015), and perceived power, an indicator of agency, has been shown to play a critical role in adaptive behavior and outcomes (Barnes et al., 2020). Despite instructions to not worry about perceived achievability of the 
conditions, some, like this participant, expressed that feasibility and the power to address certain issues affected their sorting:

Because everything is important. but I think that for me, the one thing that made it less challenging was because when I did it [the sort], I really tried to focus on thinking about things that we can make some kind of effort to address versus things that are inherent that we don't really have the ability to deal with.

A sense of agency, as with the impacts to wellbeing resulting from tradeoffs in management, can be unevenly distributed among individuals in a community (Cinner and Barnes, 2019). One of the points of consensus among discourses was the importance of including a measure of equity in fisheries management moving forward, perhaps an acknowledgement that attention must be paid towards potential unintended consequences of policies that widen the gulf between winners and losers (e.g., Carothers et al., 2010). There are places within each perspective to consider the implications of equity. Who is included in partnerships and collaborative processes? What is the distribution of vulnerability if we choose to pursue short-term versus long-term actions? Are the values of the community represented in management's vision of the future? This potentially unifying concept may be a useful touchstone when there are disagreements about the best ways to improve wellbeing. This is also an area where more than economic contribution to wellbeing must be considered. Without inclusion of more dimensions of wellbeing, tradeoffs may exacerbate marginalization and represent the values of the decision-makers instead of stakeholders, triggering conflict or opposition to policies (Daw et al., 2015).

Since Q methodology can highlight minority perspectives within a group (Watts and Stenner, 2012), this method may be well suited to bring forward the voices of individuals less well represented in fisheries management and in the literature on coastal communities. The perspectives of those in management are important for a host of reasons we have described, and the people chosen to participate in this study have a wealth of knowledge and experience as fishers and in fishery management. Because of the nature of a Q study, including small sample size and non-random participant selection, the results are not intended to be more broadly applied to the population (Brown et al., 1999). As such, the perspectives highlighted here do not encompass all the views held by those in fisheries management on the West Coast; however, they do highlight some important pathways for improving wellbeing in coastal communities. While we focused on those engaged in the management process in this study, next steps could include broadening the inquiry to residents of coastal communities. Such work could inform the development of reference points for ecosystem-based fisheries management, ensure the saliency of management for all participants, and may hold potential for the further incorporation of perspectives and social data into fisheries management (Levin et al. 2018; Dawson and Levin, 2019).

Inclusion of a holistic view of human wellbeing in fisheries management is clearly a work in progress (Breslow et al 2017), and the wellbeing of many fishing communities has certainly been challenged recently (Knight et al., 2020; Link et al., 2020; White et al., 2021). The ultimate impact of the many obstacles facing fishing communities depends in part on the diverse perspectives of actors in the fisheries sector, be it managers, advisors, or stakeholders. Daylighting discourses can help clarify foundational areas of disagreement and sharpen focus on common goals. Indeed, despite different perspectives on the priorities needed to support the wellbeing of fishing communities, the ultimate goal is shared: thriving and sustainable fisheries and fishing communities that support livelihoods, culture, and a continued connection to the environment for current generations and those to come.

\section{Appendix 1. Semi-structured Interviews}

We developed the Q set for this study using 23 semi-structured interviews that were conducted with individuals connected to fisheries on the West Coast, including people that work in the fishing industry, state or tribal agencies, NGOs, and academia. Below is an example script used in the interviews.

Example Interview Script.

Climate and Communities- Scenario Planning Project.

How will West Coast fishing communities be affected by climate related shifting stock availability and other developments between now and 2040?

Thank you for the opportunity to chat today. I am working with a team from the University of Washington to understand how people engaged in fishing, the seafood industry, or fisheries management perceive changes in fisheries over the last few years, what changes they see coming, and thoughts about dealing with these changes. Before we get started, will it be ok if I record our conversation? I will create a transcript of the interview and only our research team will have access to it. Any summary interview content, or direct quotations from the interview that are made available through academic publication will be made anonymous so that you cannot be identified, and care will be taken to ensure that other information in the interview that could identify you will not be revealed. I have 5-6 questions. They are fairly open-ended, and they're going to be geared towards getting you to just express your thoughts, questions, opinions, about how you see West Coast fishing communities evolving over the next 10 or 20 years. But first, I'd love for you to give me maybe one or 2 min on your background, and how you connect to West Coast fisheries.

1. Looking back-Over the past decade, what have been the most notable developments in West Coast fishing 
communities? What about in stock availability? Which trends surprised you most? What are the biggest story lines?

2. If I could answer any questions for you that would help you better understand the future of West Coast fishing communities (in 2040), what would you want to know? What do you not know today that you'd like to know to help have a successful fishing industry on the West Coast? You can ask about the world, the industry, the environment...

3. Thinking about the next 10 or 20 years, what do you think seems like an inevitable trend that will affect stock availability? What are the most important unstoppable or inevitable trends that you think will affect West Coast fishing communities?

4. Wildcard-What low probability events could happen to completely reshape the landscape for West Coast fishing communities?

5. Describe how a bad scenario might evolve for West Coast fishing communities in the next 20 years? Can you describe a good scenario-what might that involve?

6. Is there anything else you would like to add on these topics?

\section{Appendix 2. Environmental worldview}

A range of variables have been shown to influence people's perception of climate change risk including their environmental worldview, level of perceived personal responsibility for conservation, and political ideology (Weber, 2010; Sullivan and White, 2019). The Cultural Theory of Risk (CTR) originally developed by Mary Douglas and colleagues (Douglas 1966; Gross and Rayner 1985; Rayner 1992; Douglas and Wildavsky 1982) posits a framework of how culture and social organization inform worldviews and risk perception. In CTR, there are 4 worldviews: fatalist, egalitarian, hierarchist, and individualist. Following other work that has considered climate risk perception in the context of CTR (McNeeley and Lazrus, 2014; Cullen et al., 2018), before we had participants complete the $\mathrm{Q}$ sort, we asked them about their agreement or disagreement with four statements designed to align with each worldview:

Please indicate the degree to which you agree or disagree with the following statement:

1. There is no need to plan for climate change since we do not know exactly what is going to happen.

2. Regulations are the best way to keep us from pushing the environment past manageable limits.

3. Self-sufficiency is key to weathering natural climate variability.

4. Equity and cooperation are essential in resource management and to maintain the balance between humans and nature

We were curious is there would be any correlation between the discourses and worldviews, and while there was small variation between discourse (Fig. 5), we did not find any significant patterns.
Fig. 5 Density plot of responses to worldview questions by each discourse: a. Collaboration is Key, b. Fishers Forward, and c. Climate and Society

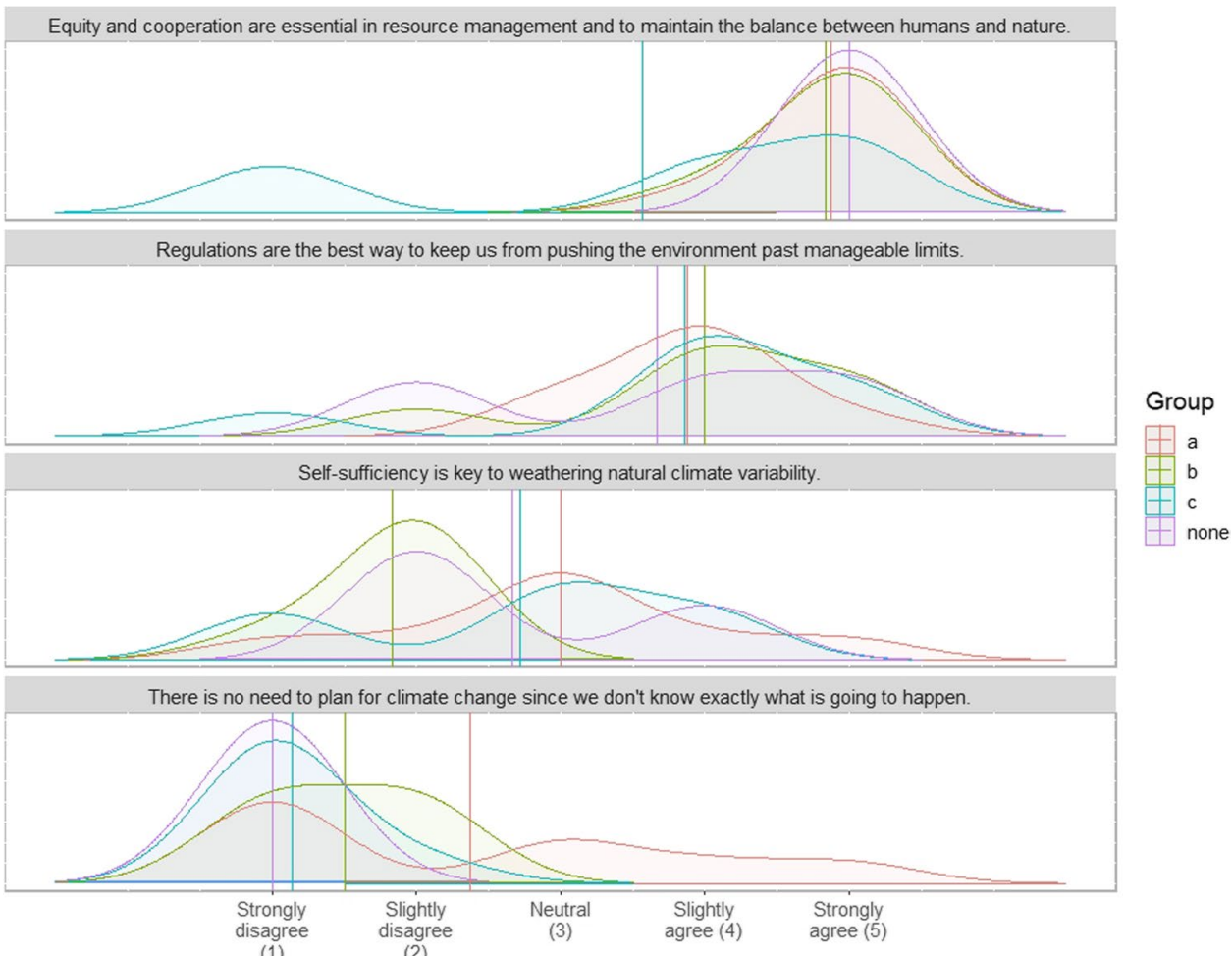




\section{Appendix 3. Detailed Q sort results}

The following tables and figures expand upon data provided in the body of the manuscript and show general factor characteristics (Table 5), support for the three-factor solution
(Table 6, Fig. 6), and the factor scores and status of each statement (Table 7).

Table 5 General factor characteristics

\begin{tabular}{|c|c|c|c|c|c|c|}
\hline & $\begin{array}{l}\text { Average reliability } \\
\text { coefficient }\end{array}$ & $\begin{array}{l}\text { Loading } Q \\
\text { sorts }\end{array}$ & Eigenvalues & $\begin{array}{l}\text { Explained vari- } \\
\text { ance }(\%)\end{array}$ & $\begin{array}{l}\text { Composite reli- } \\
\text { ability }\end{array}$ & SE factor scores \\
\hline A. Collaboration is key & 0.8 & 8 & 3.6 & 15 & 0.97 & 0.17 \\
\hline B. Fishers forward & 0.8 & 6 & 3.4 & 14 & 0.96 & 0.2 \\
\hline C. Climate and society & 0.8 & 7 & 3.2 & 13 & 0.97 & 0.19 \\
\hline
\end{tabular}

Table 6 Correlation between factor $\mathrm{z}$-scores

Fig. 6 Screeplot of unrotated factors

\begin{tabular}{llll}
\hline & $A$ & $B$ & $C$ \\
\hline$A$ & 1 & 0.36 & 0.2 \\
$B$ & 0.36 & 1 & 0.11 \\
$C$ & 0.2 & 0.11 & 1 \\
\hline
\end{tabular}

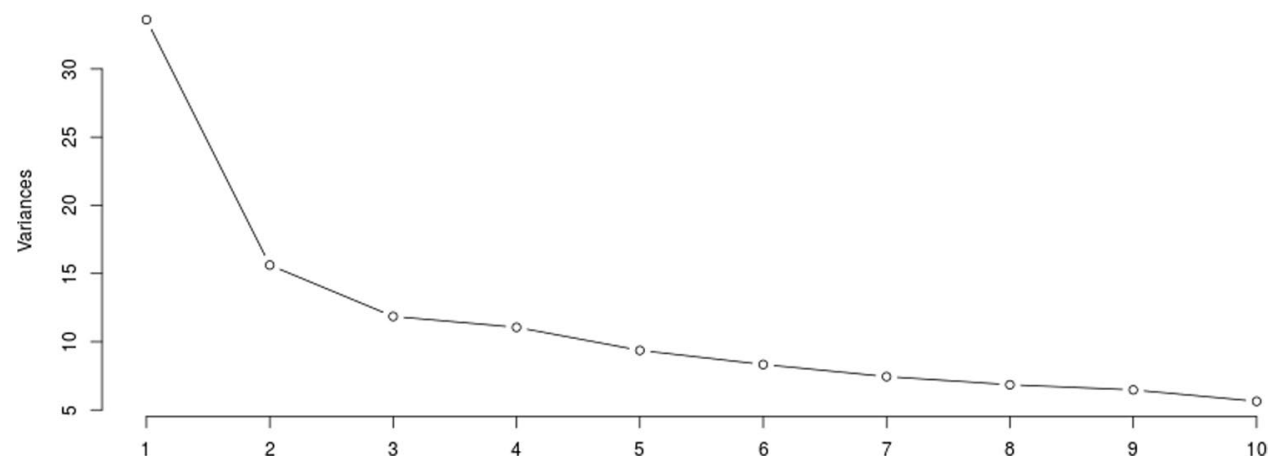




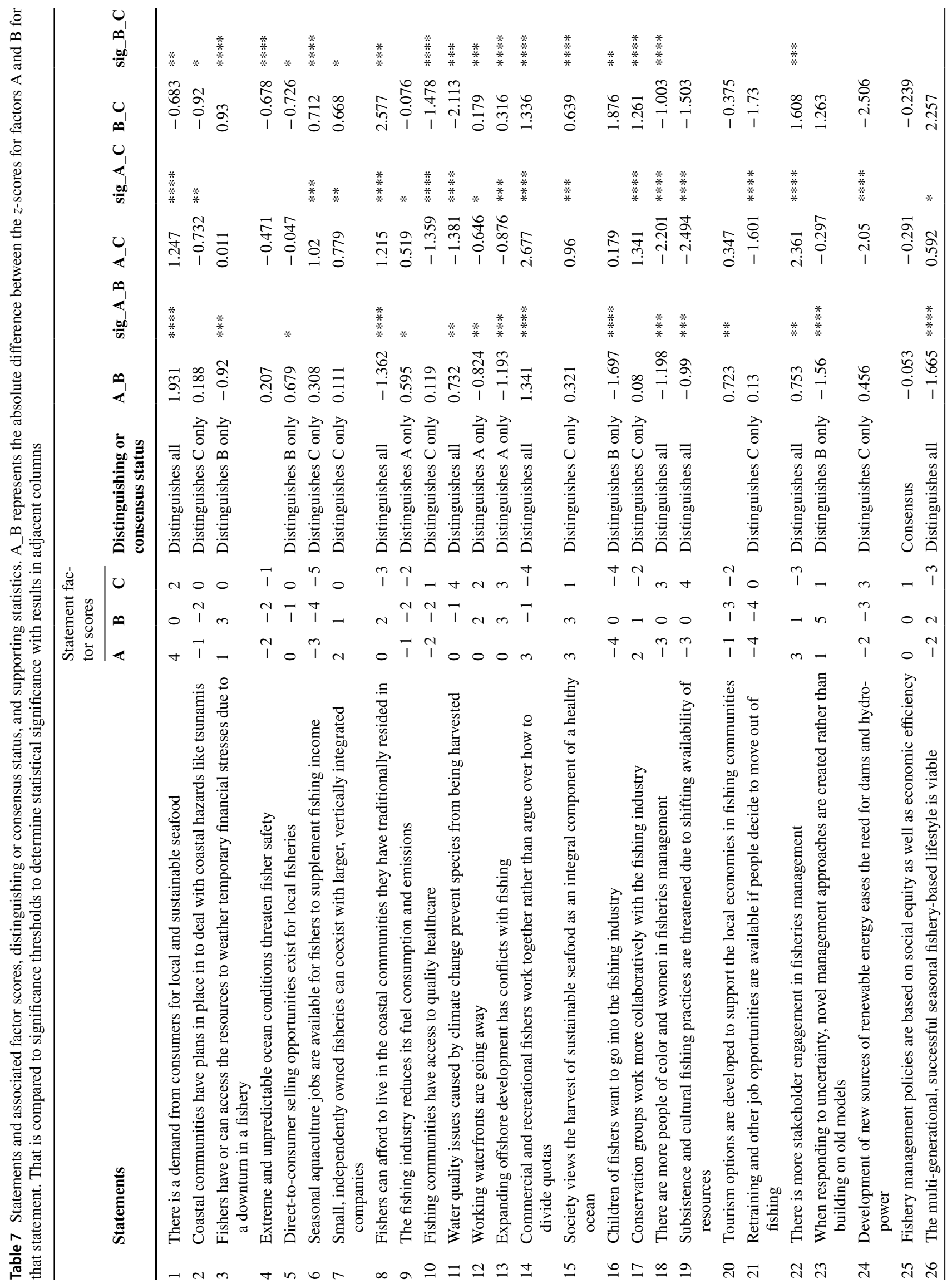




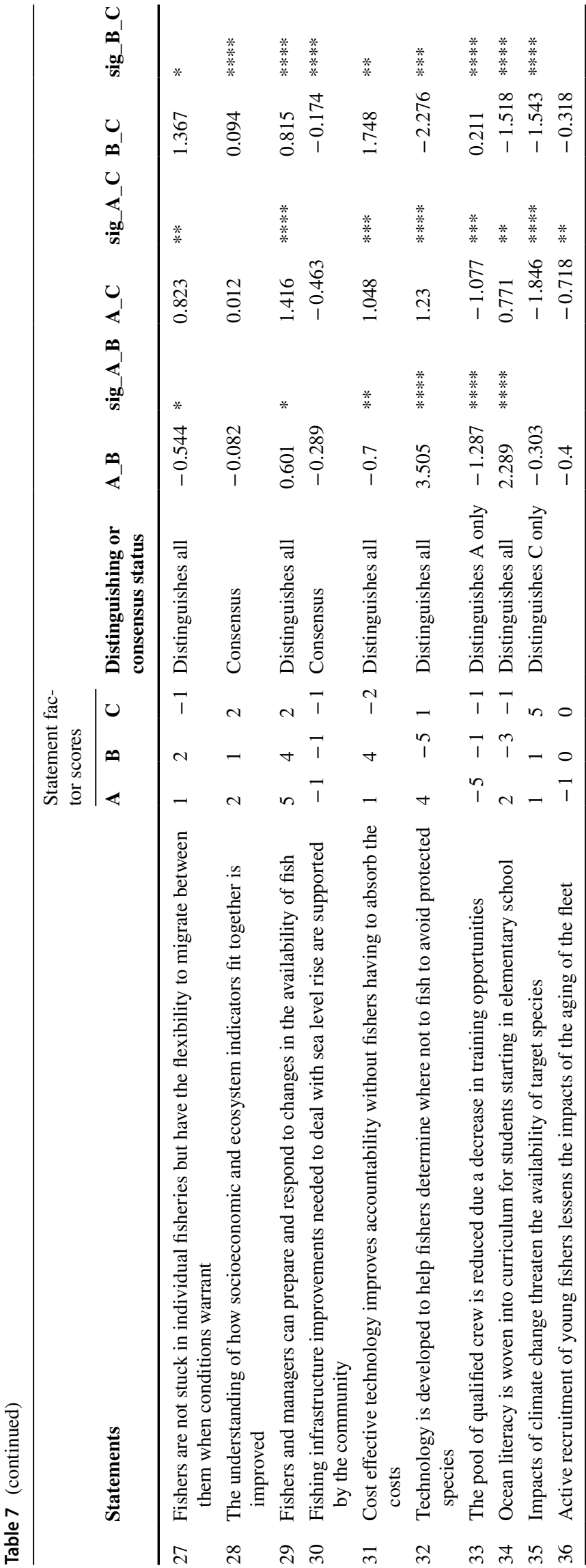

Author contributions All authors contributed to the study conception and design. Data collection was performed by Laura Nelson, Molly Bogeberg, and Astrea Strawn. Laura Nelson performed data analysis and wrote the first draft of the manuscript. All authors read and approved the final manuscript.

Funding This work was supported by the Lenfest Ocean Program.

Data availability Any data or material not protected by confidentiality will be provided upon request.

\section{Declarations}

Conflict of interest The authors have no conflict of interests to declare that are relevant to the content of this article.

Ethics approval. This study received IRB exempt status from the University of Washington (STUDY00008104).

Consent to participate. We received verbal consent from all participants in our study.

Consent for publication. Participants were informed about our intent to publish the research and consented to that provided that we ensure their anonymity.

\section{References}

Ainsworth, C., J. Samhouri, D. Busch, T. Okey, and W. Cheung. 2011. Potential impacts of climate change in northeast Pacific marine food webs. ICES Journal of Marine Science 68 (6): 1217-1229.

Armatas, C., T. Venn, and A. Watson. 2016. Understanding social-ecological vulnerability with Q-methodology: A case study of waterbased ecosystem services in Wyoming, USA. Sustainability Science 12: 105-121. https://doi.org/10.1007/s11625-016-0369-1.

Armitage, D., C. Béné, A.T. Charles, D. Johnson, and E.H. Allison. 2012. The interplay of well-being and resilience in applying a social-ecological perspective. Ecology and Society. 17 (4): 15. https://doi.org/10.5751/ES-04940-170415.

Badjeck, M.C., E.H. Allison, A.S. Halls, and N.K. Dulvy. 2010. Impacts of climate variability and change on fishery-based livelihoods. Marine Policy 34 (3): 375-383. https://doi.org/10.1016/j. marpol.2009.08.007.

Barnes, M.L., P. Wang, J.E. Cinner, J. Graham, A.M. Guerrero, L. Jasny, J. Lau, S.R. Sutcliffe, and J. Zamborain-Mason. 2020. Social determinants of adaptive and transformative responses to climate change. Nature Climate Change 10: 823-828. https:// doi.org/10.1038/s41558-020-0871-4.

Barry, J., and J. Proops. 1999. Seeking sustainability discourses with Q methodology. Ecological Economics 28 (3): 337-345. https:// doi.org/10.1016/S0921-8009(98)00053-6.

Barton, A., G.G. Waldbusser, R.A. Feely, S.B. Weisberg, J.A. Newton, B. Hales, S. Cudd, B. Eudeline, C.J. Langdon, I. Jefferds, T. King, A. Suhrbier, and K. McLaughlin. 2015. Impacts of coastal acidification on the Pacific Northwest shellfish industry and adaptation strategies implemented in response. Oceanography 28 (2): 146-159. https://doi.org/10.5670/oceanog.2015.38.

Bennett, N.J., R. Roth, S.C. Klain, K. Chan, P. Christie, D.A. Clark, G. Cullman, D. Curran, T.J. Durbin, G. Epstein, A. Greenberg, M.P. Nelson, J. Sandlos, R. Stedman, T.L. Teel, R. Thomas, D. Veríssimo, and C. Wyborn. 2017. Conservation social science: 
Understanding and integrating human dimensions to improve conservation. Biological Conservation 205: 93-108. https://doi. org/10.1016/j.biocon.2016.10.006.

Bennett, N.J., E.M. Finkbeiner, N.C. Ban, D. Belhabib, S.D. Jupiter, J.N. Kittinger, S. Mangubhai, J. Scholtens, D. Gill, and P. Christie. 2020. The COVID-19 pandemic, small-scale fisheries and coastal fishing communities. Coastal Management 48 (4): 336-347. https://doi.org/10.1080/08920753.2020.1766937.

Berkes, F. 2012. Implementing ecosystem-based management: Evolution or revolution? Fish and Fisheries 13 (4): 465-476. https:// doi.org/10.1111/j.1467-2979.2011.00452.x.

Bond, N.A., M.F. Cronin, H. Freeland, and N. Mantua. 2015. Causes and impacts of the 2014 warm anomaly in the NE Pacific. Geophysical Research Letters 42 (9): 3414-3420. https://doi.org/10. 1002/2015GL063306.

Bratman, G.N., C.B. Anderson, M.G. Berman, B. Cochran, S. de Vries, J. Flanders, C. Folke, H. Frumkin, J.J. Gross, T. Hartig, P.H. Kahn, M. Kuo, J.J. Lawler, P.S. Levin, T. Lindahl, A. MeyerLindenberg, R. Mitchell, Z. Ouyang, J. Roe, and G.C. Daily. 2019. Nature and mental health: An ecosystem service perspective. Science Advances 5 (7): 903-927. https://doi.org/10.1126/ sciadv.aax0903.

Breslow, S.J., B. Sojka, R. Barnea, X. Basurto, C. Carothers, S. Charnley, S. Coulthard, N. Dolšak, J. Donatuto, C. García-Quijano, C.C. Hicks, A. Levine, M.B. Mascia, K. Norman, M. Poe, T. Satterfield, K.S. Martin, and P.S. Levin. 2016. Conceptualizing and operationalizing human wellbeing for ecosystem assessment and management. Environmental Science and Policy 66: 250-259. https://doi.org/10.1016/j.envsci.2016.06.023.

Breslow, S.J., M. Allen, D. Holstein, B. Sojka, R. Barnea, X. Basurto, C. Carothers, S. Charnley, S. Coulthard, N. Dolšak, J. Donatuto, C. García-Quijano, C.C. Hicks, A. Levine, M.B. Mascia, K. Norman, M. Poe, T. Satterfield, and St. Martin, K., \& Levin, P. S. 2017. Evaluating indicators of human well-being for ecosystembased management. Ecosystem Health and Sustainability 3 (12): 1-18. https://doi.org/10.1080/20964129.2017.1411767.

Brown, S. 1980. Political subjectivity: Applications of Q methodology in political science. New Haven: Yale University Press.

Brown, K., and E. Westaway. 2011. Agency, capacity, and resilience to environmental change: Lessons from human development, well-being, and disasters. Annual Review Environmental Resources 36: 321-342. https://doi.org/10.1146/annurev-envir on-052610-092905.

Brown, S.R., D.W. Durning, and S. Selden. 1999. Q methodology. In Handbook of Research Methods in Public Administration, vol. 71, ed. G. Miller and M.L. Whicker, 599-673. New York: Marcel Dekker.

Cairns, R. 2012. Understanding science in conservation: A Q method approach on the Galapagos Islands. Conservation and Society 10 (3): 217-231. https://doi.org/10.4103/0972-4923.101835.

Campbell, B.M., J.A. Sayer, and B. Walker. 2010. Navigating trade-offs: Working for conservation and development outcomes. Ecology and Society 15 (2): 2. https://doi.org/10.5751/ ES-03380-150216.

Carothers, C., D.K. Lew, and J. Sepez. 2010. Fishing rights and small communities: Alaska halibut IFQ transfer patterns. Ocean and Coastal Management 53 (9): 518-523. https://doi.org/10.1016/j. ocecoaman.2010.04.014.

Carr, L.M., and W.D. Heyman. 2012. "It's About Seeing What's Actually Out There": Quantifying fishers' ecological knowledge and biases in a small-scale commercial fishery as a path toward comanagement. Ocean and Coastal Management 69: 118-132. https://doi.org/10.1016/j.ocecoaman.2012.07.018.

Chan, K.M.A., P. Balvanera, K. Benessaiah, M. Chapman, S. Díaz, E. Gómez-Baggethun, R. Gould, N. Hannahs, K. Jax, S. Klain, G.W. Luck, B. Martín-López, B. Muraca, B. Norton, K. Ott, U.
Pascual, T. Satterfield, M. Tadaki, J. Taggart, and N. Turner. 2016. Why protect nature? Rethinking values and the environment. Proceedings of the National Academy of Sciences of the United States of America 113 (6): 1462-1465. https://doi.org/10. 1073/pnas.1525002113.

Cinner, J.E., and M.L. Barnes. 2019. Social dimensions of resilience in social-ecological systems. One Earth 1: 51-56. https://doi.org/ 10.1016/j.oneear.2019.08.003.

Cinner, J.E., W.N. Adger, E.H. Allison, M.L. Barnes, K. Brown, P.J. Cohen, S. Gelcich, C.C. Hicks, T.P. Hughes, J. Lau, N.A. Marshall, and T.H. Morrison. 2018. Building adaptive capacity to climate change in tropical coastal communities. Nature Climate Change 8: 117-123. https://doi.org/10.1038/s41558-017-0065-x.

Clayton, S., P. Devine-Wright, P.C. Stern, L. Whitmarsh, A. Carrico, L. Steg, J. Swim, and M. Bonnes. 2015. Psychological research and global climate change. Nature Climate Change 5: 640-646. https://doi.org/10.1038/NCLIMATE2622.

Cohen, P.J., E.H. Allison, N.L. Andrew, J. Cinner, L.S. Evans, M. Fabinyi, L.R. Garces, S.J. Hall, C.C. Hicks, T.P. Hughes, S. Jentoft, D.J. Mills, R. Masu, E.K. Mbaru, and B.D. Ratner. 2019. Securing a just space for small-scale fisheries in the blue economy. Frontiers in Ecology and the Environment 6: 171. https://doi. org/10.3389/fmars.2019.00171.

Colburn, L.L., M. Jepson, C. Weng, T. Seara, J. Weiss, and J.A. Hare. 2016. Indicators of climate change and social vulnerability in fishing dependent communities along the Eastern and Gulf Coasts of the United States. Marine Policy 74: 323-333. https://doi.org/10.1016/j.marpol.2016.04.030.

Coulthard, S. 2012. Can we be both resilient and well, and what choices do people have? Incorporating agency into the resilience debate from a fisheries perspective. Ecology and Society 17 (1): 4. https://doi.org/10.5751/ES-04483-170104.

Coulthard, S., D. Johnson, and J.A. McGregor. 2011. Poverty, sustainability, and human wellbeing: A social wellbeing approach to the global fisheries crisis. Global Environmental Change 21 (2): 453-463. https://doi.org/10.1016/j.gloenvcha.2011.01.003.

Crozier, L.G., M.M. McClure, T. Beechie, S.J. Bograd, D.A. Boughton, M. Carr, T.D. Cooney, J.B. Dunham, C.M. Greene, M.A. Haltuch, E.L. Hazen, D.M. Holzer, D.D. Huff, R.C. Johnson, C.E. Jordan, I.C. Kaplan, S.T. Lindley, N.J. Mantua, P.B. Moyle, and E. Willis-Norton. 2019. Climate vulnerability assessment for Pacific salmon and steelhead in the California Current Large Marine Ecosystem. PLoS ONE 14 (7): e0217711. https://doi.org/10.1371/journal.pone.0217711.

Cullen, A., and C.L. Anderson. 2017. Perception of climate risk among rural farmers in Vietnam consistency within households and with the empirical record. Risk Analysis 37 (3): 531-545. https://doi.org/10.1111/risa.12631.

Cullen, A.C., C.L. Anderson, P. Biscaye, and T.W. Reynolds. 2018. Variability in Cross-domain risk perception among smallholder farmers in Mali by gender and other demographic and attitudinal characteristics. Risk Analysis 38 (7): 1361-1377.

Damen, T.G.E. 2019. Sense of agency as a predictor of risk-taking. Acta Psychologica 197: 10-15. https://doi.org/10.1016/j.actpsy.2019.04.015.

Daw, T.M., S. Coulthard, W.W.L. Cheung, K. Brown, C. Abunge, D. Galafassi, G.D. Peterson, T.R. Mcclanahan, J.O. Omukoto, and L. Munyi. 2015. Evaluating taboo trade-offs in ecosystems services and human well-being. PNAS 112 (22): 6949-6954. https://doi.org/10.1073/pnas.1414900112.

Dawson, C., and P.S. Levin. 2019. Moving the ecosystem-based fisheries management mountain begins by shifting small stones: A critical analysis of EBFM on the US West Coast. Marine Policy 100: 58-65.

Díaz, S., Demissew, S., Carabias, J., Joly, C., Lonsdale, M., Ash, N., Larigauderie, A., Adhikari, J. R., Arico, S., Báldi, A., 
Bartuska, A., Baste, I. A., Bilgin, A., Brondizio, E., Chan, K. M. A., Figueroa, V. E., Duraiappah, A., Fischer, M., Hill, R., ... Zlatanova, D. 2015. The IPBES Conceptual Framework - connecting nature and people. In Current Opinion in Environmental Sustainability, 14. https://doi.org/10.1016/j.cosust. 2014.11.002

Donatuto, J., T. Satterfield, and R. Gregory. 2011. Poisoning the body to nourish the soul: Prioritizing health risks and impacts in a Native American community. Health, Risk and Society 13 (2): 103-127. https://doi.org/10.1080/13698575.2011.556186.

Donatuto, J., L. Campbell, and W. Trousdale. 2020. The "value" of values-driven data in identifying Indigenous health and climate change priorities. Climatic Change 158: 161-180. https://doi.org/ 10.1007/s10584-019-02596-2.

Doney, S.C., M. Ruckelshaus, J.E. Duffy, J.P. Barry, F. Chan, C.A. English, H.M. Galindo, J.M. Grebmeier, A.B. Hollowed, N. Knowlton, J. Polovina, N.N. Rabalais, W.J. Sydeman, and L.D. Talley. 2012. Climate change impacts on marine ecosystems. Annual Review of Marine Science 4: 11-37. https://doi.org/10. 1146/annurev-marine-041911-111611.

Eiser, R.J., A. Bostrom, I. Burton, D.M. Johnston, J. McClure, D. Paton, J. van der Pligt, and M.P. White. 2012. Risk interpretation and action: A conceptual framework for responses to natural hazards. International Journal of Disaster Risk Reduction 1: 5-16. https://doi.org/10.1016/j.ijdrr.2012.05.002.

Feist, B.E., and P.S. Levin. 2016. Novel indicators of anthropogenic influence on marine and coastal ecosystems. Frontiers in Marine Science 3: 113. https://doi.org/10.3389/fmars.2016.00113.

Fisher, M.C., S.K. Moore, S.L. Jardine, J.R. Watson, and J.F. Samhouri. 2021. Climate shock effects and mediation in fisheries. PNAS 118 (2) e2014379117. https://doi.org/10.1073/pnas.20143 79117/-/DCSupplemental.

Folke, C., S.R. Carpenter, B. Walker, M. Scheffer, T. Chapin, and J. Rockstrom. 2010. Resilience thinking: Integrating resilience, adaptability and transformability. Ecology and Society 15 (4): 20.

Frumkin, H., G.N. Bratman, S.J. Breslow, B. Cochran, P.H. Kahn, J.J. Lawler, P.S. Levin, P.S. Tandon, U. Varanasi, K.L. Wolf, and S.A. Wood. 2017. Nature contact and human health: a research agenda. Environmental Health Perspectives 125 (7): 075001. https://doi.org/10.1289/EHP1663.

Gruber, J. S. 2011. Perspectives of effective and sustainable community-based natural resource management: an application of Q methodology to forest projects. Conservation and Society, 9(2), 159. https://doi.org/10.4103/0972-4923.83725

Harvey, C. N. Garfield, G. Williams, N. Tolimieri, K. Andrews, K. Barnas, E. Bjorkstedt, S. Bograd, J. Borchert, C. Braby, R. Brodeur, B. Burke, J. Cope, A. Coyne, D. Demer, L. deWitt, J. Field, J. Fisher, P. Frey, T., ... Zwolinski, J. 2020. Ecosystem status report of the California Current for 2019-20: a summary of ecosystem indicators compiled by the California Current Integrated Ecosystem Assessment Team (CCIEA). U.S. Department of Commerce, NOAA Technical Memorandum NMFS-NWFSC-160. https:// doi.org/10.25923/e5rb-9f55

Hicks, C.C., T.R. McClanahan, J.E. Cinner, and J.M. Hills. 2009. Trade-offs in values assigned to ecological goods and services associated with different coral reef management strategies. Ecology and Society 14 (1): 140110. https://doi.org/10.5751/ ES-02712-140110.

Hicks, C.C., A. Levine, A. Agrawal, X. Basurto, S.J. Breslow, C. Carothers, S. Charnley, S. Coulthard, N. Dolsak, J. Donatuto, C. Garcia-Quijano, M.B. Mascia, K. Norman, M.R. Poe, T. Satterfield, and St. Martin, K., \& Levin, P. S. 2016. Engage key social concepts for sustainability. Science 352 (6281): 38-40. https:// doi.org/10.1126/science.aad4977.

Hodgson, E.E., I.C. Kaplan, K.N. Marshall, J. Leonard, T.E. Essington, D.S. Busch, E.A. Fulton, C.J. Harvey, A. Hermann, and
P. McElhany. 2018. Consequences of spatially variable ocean acidification in the California Current: Lower $\mathrm{pH}$ drives strongest declines in benthic species in southern regions while greatest economic impacts occur in northern regions. Ecological Modelling 383: 106-117. https://doi.org/10.1016/j.ecolmodel.2018. 05.018 .

Holland, D.S., J.K. Abbott, and K.E. Norman. 2019. Fishing to live or living to fish: Job satisfaction and identity of west coast fishermen. Ambio. https://doi.org/10.1007/s13280-019-01206-w.

Ibrahim, S., and S. Alkire. 2007. Agency and Empowerment: A proposal for internationally comparable indicators. Oxford Development Studies 35 (4): 379-403. https://doi.org/10.1080/13600 810701701897.

IPCC. 2019. Technical summary [H.-O. Pörtner, D.C. Roberts, V. Masson-Delmotte, P. Zhai, E. Poloczanska, K. Mintenbeck, M. Tignor, A. Alegría, M. Nicolai, A. Okem, J. Petzold, B. Rama, N.M. Weyer (eds.)]. In: IPCC Special Report on the Ocean and Cryosphere in a Changing Climate [H.- O. Pörtner, D.C. Roberts, V. Masson-Delmotte, P. Zhai, M. Tignor, E. Poloczanska, K. Mintenbeck, A. Alegría, M. Nicolai, A. Okem, J. Petzold, B. Rama, N.M. Weyer (eds.)]. In press.

Kittinger, J.N., J.Z. Koehn, E. Le Cornu, N.C. Ban, M. Gopnik, M. Armsby, C. Brooks, M.H. Carr, J.E. Cinner, A. Cravens, M. D’Iorio, A. Erickson, E.M. Finkbeiner, M.M. Foley, R. Fujita, S. Gelcich, K.S. Martin, E. Prahler, D.R. Reineman, and L.B. Crowder. 2014. A practical approach for putting people in ecosystem-based ocean planning. Frontiers in Ecology and the Environment 12 (8): 448-456. https://doi.org/10.1890/130267.

Knight, C.J., T.L. Burnham, E.J. Mansfield, L.B. Crowder, and F. Micheli. 2020. COVID-19 reveals vulnerability of small-scale fisheries to global market systems. The Lancet Planetary Health 4 (6): 219.

Lebel, L., J.M. Anderies, B. Campbell, C. Folke, S. Hatfield-Dodds, T.P. Hughes, and J. Wilson. 2006. Governance and the capacity to manage resilience in regional social-ecological systems. Ecology and Society 11 (1): 110119. https://doi.org/10.5751/ ES-01606-110119.

Levin, P.S., M.J. Fogarty, S.A. Murawski, and D. Fluharty. 2009. Integrated ecosystem assessments: Developing the scientific basis for ecosystem-based management of the ocean. PLoS Biology 7 (1): e1000014. https://doi.org/10.1371/journal.pbio.1000014.

Levin, P.S., G.D. Williams, A. Rehr, K.C. Norman, and C.J. Harvey. 2015. Developing conservation targets in social-ecological systems. Ecology and Society 20 (4): 200406. https://doi.org/10. 5751/ES-07866-200406.

Levin, P.S., S.J. Breslow, C.J. Harvey, K.C. Norman, M.R. Poe, G.D. Williams, and M.L. Plummer. 2016. Conceptualization of socialecological systems of the California Current: An examination of interdisciplinary science supporting ecosystem-based management. Coastal Management 44 (5): 397-408. https://doi.org/10. 1080/08920753.2016.1208036.

Levin, P.S., T.E. Essington, K.N. Marshall, L.E. Koehn, L.G. Anderson, A. Bundy, C. Carothers, F. Coleman, L.R. Gerber, J.H. Grabowski, and E. Houde. 2018. Building effective fishery ecosystem plans. Marine Policy 92: 48-57.

Levin, P.S., S.A. Gray, C. Möllmann, and A.C. Stier. 2021. Perception and conflict in conservation: The Rashomon effect. BioScience 71 (1): 64-72. https://doi.org/10.1093/biosci/biaa117.

Link, J. 2010. Ecosystem-based fisheries management: Confronting tradeoffs. Cambridge University Press.

Link, J.S., F.E. Werner, K. Werner, J. Walter, M. Strom, M.P. Seki, F. Schwing, J. Rusin, C.E. Porch, K. Osgood, and K. Moline. 2021. A NOAA Fisheries science perspective on the conditions during and after COVID-19: Challenges, observations, and some possible solutions, or why the future is upon us. Canadian Journal of Fisheries and Aquatic Sciences 78 (1): 1-12. 
Loring, P.A., and M.S. Hinzman. 2018. “They're All Really Important, But...”: Unpacking how people prioritize values for the marine environment in Haida Gwaii, British Columbia. Ecological Economics 152: 367-377. https://doi.org/10.1016/j.ecolecon.2018. 06.020 .

Love, D., Allison, E., Asche, F., Belton, B., Cottrell, R., Froehlich, H., Gephart, J., Hicks, C., Little, D., Nussbaumer, E., da Silva, P. P., Poulain, F., Rubio, A., Stoll, J., Tlusty, M., Thorne-Lyman, A., Troell, M., \& Zhang, W. 2020. Emerging COVID-19 impacts, responses, and lessons for building resilience in the seafood system. SocArXiv. https://doi.org/10.31235/osf.io/x8aew

Lutfallah, S., and L. Buchanan. 2019. Quantifying subjective data using online Q-methodology software. The Mental Lexicon 14 (3): 415-423. https://doi.org/10.1075/ml.20002.lut.

Macdonald, P.A., G. Murray, and M. Patterson. 2015. Considering social values in the seafood sector using the Q-method. Marine Policy 52: 68-76. https://doi.org/10.1016/j.marpol.2014.10.029.

Marshall, N.A., S.E. Park, N.E. Adger, K. Brown, and S.M. Howden. 2012. Transformational capacity and the influence of place and identity. Environmental Research Letters 7 (3): 034032.

McGregor, J.A. 2008. Wellbeing, poverty, and conflict. WeD Policy Briefing. http://www.bath.ac.uk/soc-pol/welldev/research/bp/ bp1-08.pdf

McNeeley, S.M., and H. Lazrus. 2014. The cultural theory of risk for climate change adaptation. Weather, Climate, and Society 6 (4): 506-519. https://doi.org/10.1175/WCAS-D-13-00027.1.

Moore, S.K., S.J. Dreyer, J.A. Ekstrom, K. Moore, K. Norman, T. Klinger, E.H. Allison, and S.L. Jardine. 2020. Harmful algal blooms and coastal communities: socioeconomic impacts and actions taken to cope with the 2015 U.S. West Coast domoic acid event. Harmful Algae 96: 101799. https://doi.org/10.1016/j. hal.2020.101799.

National Marine Fisheries Service. 2017. Fisheries economics of the United States Report, 2015, U.S. Dept. Commerce. NOAA Tech. Memo. NMFS-F/SPO-170, 247p.

National Marine Fisheries Service. 2018. Fisheries economics of the United States, 2016. U.S. Dept. of Commerce, NOAA Tech. Memo. NMFS-F/SPO-187, 243 p.

Nelson, D.R., W.N. Adger, and K. Brown. 2007. Adaptation to environmental change: Contributions of a resilience framework. Annual Review of Environment and Resources 32: 395-419. https://doi. org/10.1146/annurev.energy.32.051807.090348.

NOAA. 2014. "What percentage of the American Population lives near the coast?" https://oceanservice.noaa.gov/facts/population. html\#: :text=Though\%20home\%20to\%20almost\%2040,people\% 20live\%20in\%20coastal\%20counties.

Norman, K., Sepez, J., Lazrus, H., Milne, N., Package, C., Russell, S., Grant, K., Lewis, R. P., Primo, J., Springer, E., Styles, M., Tilt, B., \& Vaccaro, I. 2007. Community profiles for West Coast and North Pacific fisheries-Washington, Oregon, California, and other U.S. states. U.S. Dept. Commer., NOAA Tech. Memo. NMFS-NWFSC-85, $602 \mathrm{p}$.

Okamoto, D.K., M.R. Poe, T.B. Francis, A.E. Punt, P.S. Levin, A.O. Shelton, D.R. Armitage, J.S. Cleary, S.C. Dressell, R. Jones, H. Kitka, L.C. Lee, A.D. MacCall, J.A. McIsaac, S. Reifenstuhl, J.J. Silver, J.O. Schmidt, T.F. Thornton, R. Voss, and J. Woodruff. 2020. Attending to spatial social-ecological sensitivities to improve trade-off analysis in natural resource management. Fish and Fisheries 21: 1-12. https://doi.org/10.1111/faf.12409.

Olsen, E., I.C. Kaplan, C. Hansen, E. Fulton, M.J. Fogarty, J.C. Tam, and S.A. Otto. 2020. Editorial: Future oceans under multiple stressors: From global change to anthropogenic impact. Frontiers in Marine Science 7: 606538. https://doi.org/10.3389/fmars. 2020.606538.
Ostrom, E. 2009. A general framework for analyzing sustainability of social-ecological systems. Science 325 (July): 419-423. https:// doi.org/10.1126/science.1226338.

Perry, R.I., R.E. Ommer, M. Barange, and F. Werner. 2010. The challenge of adapting marine social-ecological systems to the additional stress of climate change. Current Opinion in Environmental Sustainability 2: 356-363. https://doi.org/10.1016/j.cosust. 2010.10.004.

Perry, A. L., Low, P. J., Ellis, J. R., \& Reynolds, J. D. 2005. Climate change and distribution shifts in marine fishes. Science, 308(5730), 1912 - 1915.

Pike, K., P. Wright, B. Wink, and S. Fletcher. 2015. The assessment of cultural ecosystem services in the marine environment using Q methodology. Source: Journal of Coastal Conservation 19 (5): 667-675. https://doi.org/10.1007/S11852-014-0350-Z.

Poe, M.R., K.C. Norman, and P.S. Levin. 2014. Cultural dimensions of socioecological systems: Key connections and guiding principles for conservation in coastal environments. Conservation Letters 7 (3): 166-175. https://doi.org/10.1111/conl.12068.

Poe, M.R., J. Donatuto, and T. Satterfield. 2016. "Sense of Place": Human wellbeing considerations for ecological restoration in Puget sound. Coastal Management 44 (5): 409-426. https://doi. org/10.1080/08920753.2016.1208037.

Pollnac, R.B., and J.J. Poggie. 2008. Happiness, well-being, and psychocultural adaptation to the stresses associated with marine fishing. Human Ecology Review 15 (2): 194-200.

Ray, L. 2011. Using Q-methodology to identify local perspectives on wildfires in two Koyukon athabascan communities in rural Alaska. Sustainability: Science, Practice, and Policy 7 (2): 18-29. https://doi.org/10.1080/15487733.2011.11908070.

Renn, O. 2008. Concepts of risk: an interdisciplinary review part 1: disciplinary risk concepts. Gaia, 17(1), 50-66.

Rockeach, M. 2008. Understanding human values. New York: Free Press.

Sale, P.F., T. Agardy, C.H. Ainsworth, B.E. Feist, J.D. Bell, P. Christie, O. Hoegh-Guldberg, P.J. Mumby, D.A. Feary, M.I. Saunders, T.M. Daw, S.J. Foale, P.S. Levin, K.C. Lindeman, K. Lorenzen, R.S. Pomeroy, E.H. Allison, R.H. Bradbury, J. Corrin, and C.R.C. Sheppard. 2014. Transforming management of tropical coastal seas to cope with challenges of the 21st century. Marine Pollution Bulletin 85 (1): 8-23. https://doi.org/10.1016/j.marpo lbul.2014.06.005.

Sandbrook, C.G., J.A. Fisher, and B. Vira. 2013. What do conservationists think about markets? Geoforum 50: 232-240.

Satterfield, T., R. Gregory, S. Klain, M. Roberts, and K.M. Chan. 2013. Culture, Intangibles, and metrics in environmental management. Journal of Environmental Management 117: 103-114. https:// doi.org/10.1016/j.jenvman.2012.11.033.

Selig, E.R., D.G. Hole, E.H. Allison, K.K. Arkema, M.C. McKinnon, J. Chu, A. de Sherbinin, B. Fisher, L. Gallagher, M.B. Holland, J.C. Ingram, N.S. Rao, R.B. Russell, T. Srebotnjak, L.C.L. Teh, S. Troëng, W.R. Turner, and A. Zvoleff. 2018. Mapping global human dependence on marine ecosystems. Conservation Letters 12: e12617. https://doi.org/10.1111/conl.12617.

Sen, A. 1985. Well-being, agency, and freedom: The Dewey lectures 1984. The Journal of Philosophy 82 (4): 169-221. https://doi. org/10.2307/2026184.

Sojka, B., 2014. Integrating human wellbeing assessment into marine resource management. MA Thesis. University of Washington, Seattle, WA.

Stephenson, W. 1953. The study of behavior: Q-technique and its methodology. Chicago: University of Chicago Press.

Stoll, J.S., H.L. Harrison, E. De Sousa, D. Callaway, M. Collier, K. Harrell, B. Jones, J. Kastlunger, E. Kramer, S. Kurian, M.A. Lovewell, S. Strobel, T. Sylvester, B. Tolley, A. Tomlinson, E.R. White, T. Young, and P.A. Loring. 2021. Alternative seafood 
networks during COVID-19: Implications for resilience and sustainability. Frontiers in Sustainable Food Systems 5: 614368. https://doi.org/10.3389/fsufs.2021.614368.

Thiault, L., S. Gelcich, N. Marshall, P. Marshall, F. Chlous, and J. Claudet. 2020. Operationalizing vulnerability for social-ecological integration in conservation and natural resource management. Conservation Letters 13 (1): 12677. https://doi.org/10.1111/conl. 12677.

Watts, S., and P. Stenner. 2005. Doing Q methodology: Theory, method, and interpretation. Qualitative Research in Psychology 2 (1): 67-91.

Watts, S., and P. Stenner. 2012. Doing Q methodological research: theory, method, and interpretation. Los Angeles: SAGE.

Webler, T., Danielson, S., \& Tuler, S. 2009. Using Q method to reveal social perspectives in environmental research. Greenfield MA: Social and Environmental Research Institute. http://www.seri-us. org/pubs/Qprimer.pdf

Wells, M.L., V.L. Trainer, T.J. Smayda, B.S.O. Karlson, C.G. Trick, R.M. Kudela, A. Ishikawa, S. Bernard, A. Wulff, D.M. Anderson, and W.P. Cochlan. 2015. Harmful algal blooms and climate change: Learning from the past and present to forecast the future.
Harmful Algae 49: 68-93. https://doi.org/10.1016/j.hal.2015.07. 009.

White, E.R., H.E. Froehlich, J.A. Gephart, R.S. Cottrell, T.A. Branch, R. Agrawal Bejarano, and J.K. Baum. 2021. Early effects of COVID-19 on US fisheries and seafood consumption. Fish and Fisheries 22 (1): 232-239. https://doi.org/10.1111/faf.12525.

Willis, C., E. Papathanasopoulou, D. Russel, and Y. Artioli. 2018. Harmful algal blooms: The impacts on cultural ecosystem services and human well-being in a case study setting, Cornwall, UK. Marine Policy 97: 232-238. https://doi.org/10.1016/j.marpol.2018.06.002.

Zabala, A., C. Sandbrook, and N. Mukherjee. 2018. When and how to use Q methodology to understand perspectives in conservation research. Conservation Biology 32 (5): 1185-1194. https://doi. org/10.1111/cobi.13123.

Zabala, A. 2014. qmethod: a package to explore human perspectives using Q methodology. The R Journal, 6(2), 162-173. https:// journal.r-project.org/archive/2014-2/zabala.pdf.

Publisher's note Springer Nature remains neutral with regard to jurisdictional claims in published maps and institutional affiliations. 